\title{
Pleural Mesothelioma Clinical Distant Metastasis TNM Finding v7
}

National Cancer Institute

\section{Source}

National Cancer Institute. Pleural Mesothelioma Clinical Distant Metastasis TNM Finding v7. NCI Thesaurus. Code C88915.

A clinical finding about one or more characteristics of pleural mesothelioma, following the rules of the TNM AJCC V7 classification system as they pertain to distant metastases. 